\title{
Al and Nanotechnology for Healthcare: A survey
}

\author{
Bhupesh Rawat ${ }^{1}$, Ankur Singh Bist ${ }^{2}$, Dedeh Supriyanti ${ }^{3}$, Vonda Elmanda ${ }^{4}$, \\ Siti Nurindah Sari ${ }^{5}$ \\ 1,2 Graphic Era Hill University Bhimtal Campus \\ 3,4,5 University of Raharja \\ ${ }^{1,2}$ Road Society Area, Oghal Bhatta, Clement Town, Dehradun, Uttarakhand 248002, India. \\ 3,4,5Modern, Jl. Jenderal Sudirman No.40, Cikokol, Kec. Tangerang, Kota Tangerang, Banten \\ 15117. \\ e-mail: bhr222@gmail.com¹, ankur1990bist@gmail.com² ${ }^{2}$ dedeh@raharja.info³ \\ vonda.elmanda@raharja.info ${ }^{4}$, siti.nurindah@raharja.info ${ }^{5}$.
}

To cite this document :

Rawat, B., Bist, A.S., Supriyanti, D., Elmanda, V., \& Sari, S.N. (2023) Al and Nanotechnology for Healthcare: A survey. Aptisi Transactions on Management (ATM), 7(1), 86-91.

DOI :

https://doi.org/10.33050/atm.v7i1.1819

\begin{abstract}
Al is today's wave of technology, and it caters to various problems. One of them is Nanotechnology. Nanotechnology is another thread of technology. The use of nanotechnology is well known, including in the health sector, cosmetic industry, and agriculture. The role of $\mathrm{Al}$ in healthcare is broad, from detecting lung disease to skin analysis. This study aims to explore healthcare possibilities by integrating $A l$ and nanotechnology. The method of applying nanotechnology in the health sector uses a Nanomedicine Microscope. Nanomedicine is the medical application of nanotechnology used to diagnose, monitor, and control biological systems. Therefore, the author uses the Nanomedicine Microscope as the object in this study because the wonders of nanotechnology in various operations are also well established. The novelty in this paper focuses on Al and Nanotechnology together as possibilities for healthcare. Al and nanotechnology are two critical technologies. The ultimate goal is to integrate the uses and possibilities of these two technologies and do wonders in the healthcare domain. This study will benefit those working in Al and medicine. Nanotechnology integrating Al technology into the medical industry enables many conveniences, including task automation and analyzing large amounts of patient data for better, faster, and more affordable healthcare.
\end{abstract}

Keywords: Al, healthcare, nanotechnology.

\section{Introduction}

Artificial intelligence $(\mathrm{Al})$ is defined as the intelligence of machines instead of the intelligence of humans or other living species[1]. Al has shown its potential in various fields, including online shopping, marketing, intelligent cars, social media, surveillance, and customer service [2]. Healthcare is an emerging field where medical professionals use it extensively to solve medical problems such as diseases diagnosis [3], end-to-end drug discovery, improving communication between doctor and patient[4], transcribing medical documents such as prescription, and remotely treating patients [5]. With the emergence of Nanotechnology, the power of Al has increased tremendously, especially in the field of healthcare [6]. Nanotechnology or nanoscience refers to the research and development of applied science at the atomic or molecular level (i.e., molecular engineering, manufacturing)[7]. Integration of $\mathrm{Al}$ and nanotechnology can open ways for various 
technological developments and a large variety of disciplines[8]. This paper aims to explore possibilities for healthcare by integrating $\mathrm{Al}$ and nanotechnology[9].

The following section discusses how the healthcare system has made significant improvements by integrating Al and nanotechnology[10]. Nanotechnology is the creation of functional materials, devices, and systems through the manipulation of matter at a length scale of 1-100 nm"[11]. DNA Manipulation and Gene Therapy, drug delivery, and nanofibers are areas where nanotechnology has delivered results[12][13].

\section{Method}

\section{a. Using Nanotechnology to Predict Personalized Drug Potency}

Personalized drug discovery is the need of the hour as we can see multiple cases where acute situations can be tackled only when this objective is adequately addressed [14].

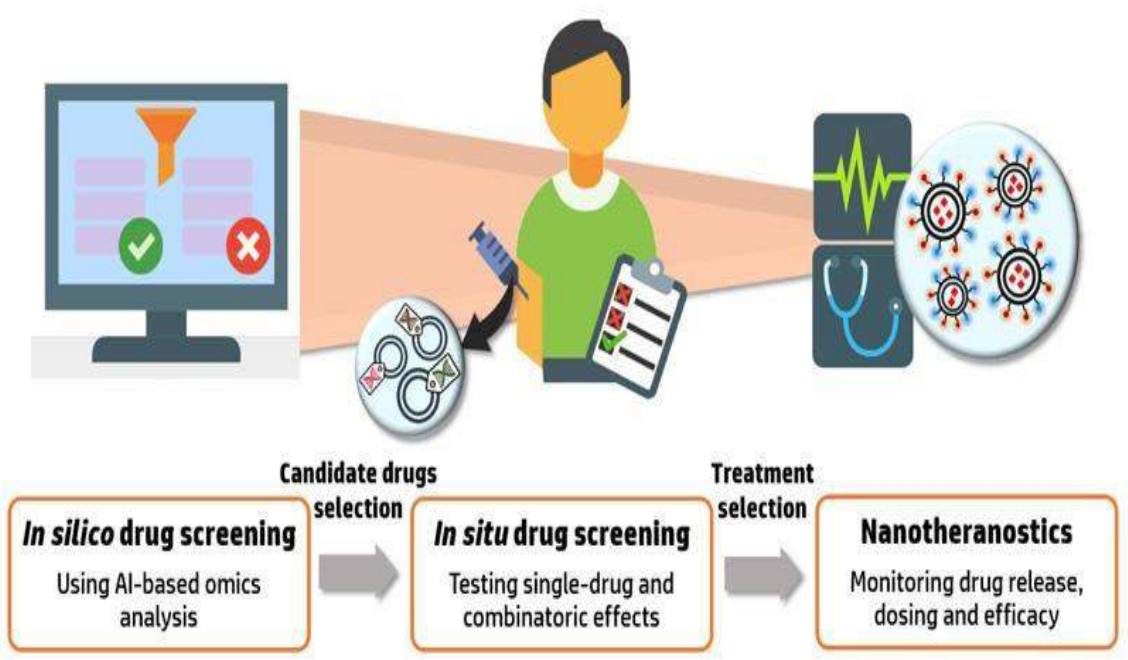

Figure 1. Exploiting Al and nanomedicine for tailoring a patient-specific treatment regime

\section{b. Microscopy}

Although a significant advance has been made in microscopy, getting high-quality signals from these devices[15]. The main reason is that these images possess tips to possess sample complex interactions [16], vary, and are difficult to decipher. This is where Al can be beneficial in dealing with signal-related issues[17]. 


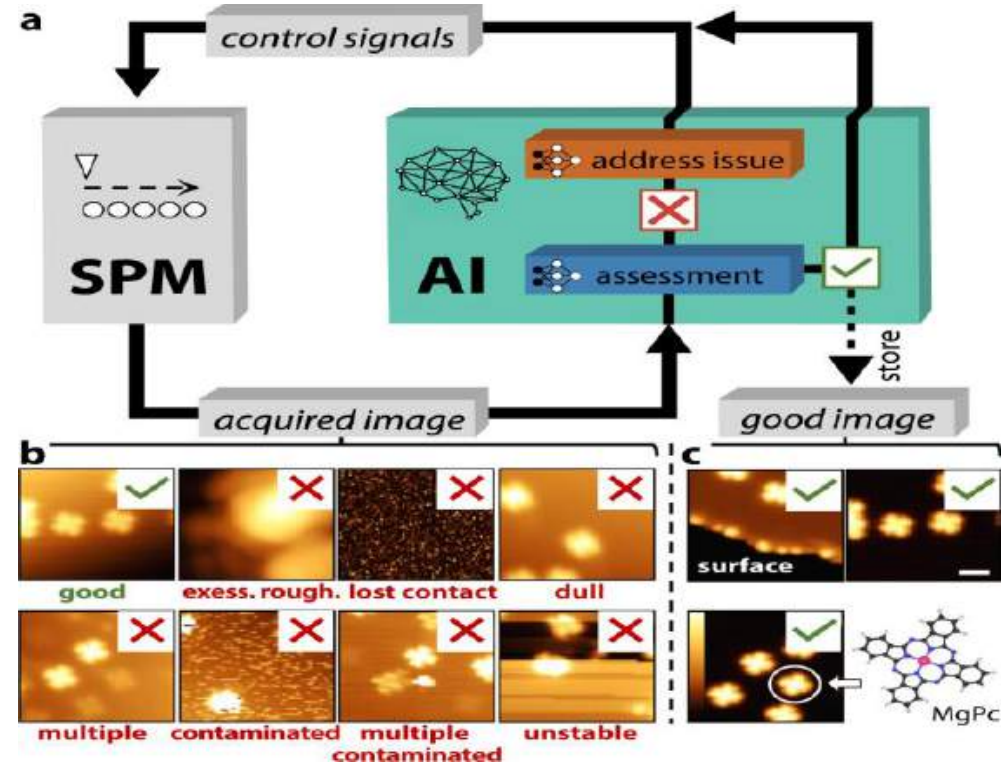

Figure 2. Schematic of Deeps, a machine learning (ML)-based Al system for autonomous scanning probe microscopy operation

\section{c. Computation in Nanotherapeutics - Targeting and Personalized Dosing}

Integrating the power of $\mathrm{Al}$ and nanotechnology is giving rise to various solutions in the medical domain[18][19]. Finding out precision cancer medicine, improving vascular hypertension, tumor diagnosis, etc., are the use cases and potential of this combination[20].

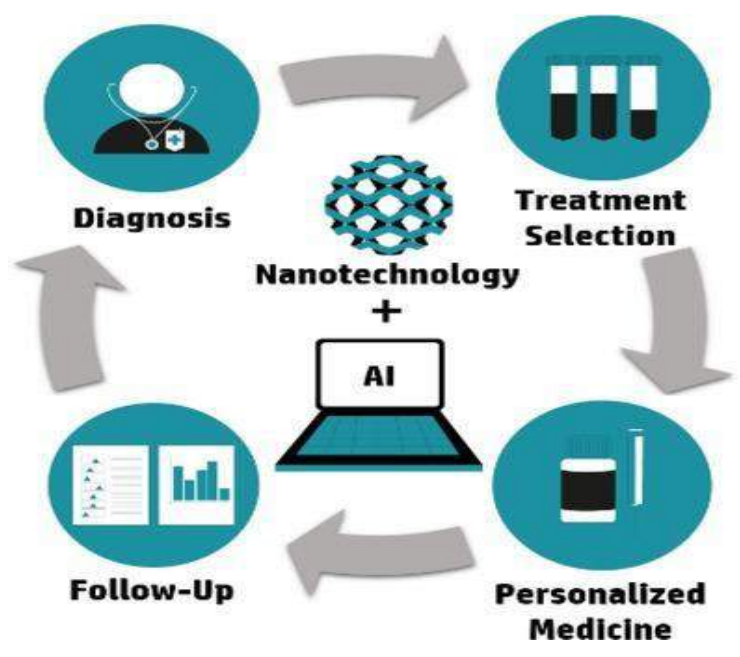

Figure 3. Al and nanotechnology integration

\section{d. Deciding when to use Nanomedicine Microscopy}

Medical experts can decide the need for nanomedicine microscopy based on their experience and practice[21][22]. Al can be helpful to assist them in terms of making accurate decisions where experience can join hands with added experience into machines[23]. This concept has been derived in Biomedical imaging and is relatively stable now[24][25]. 


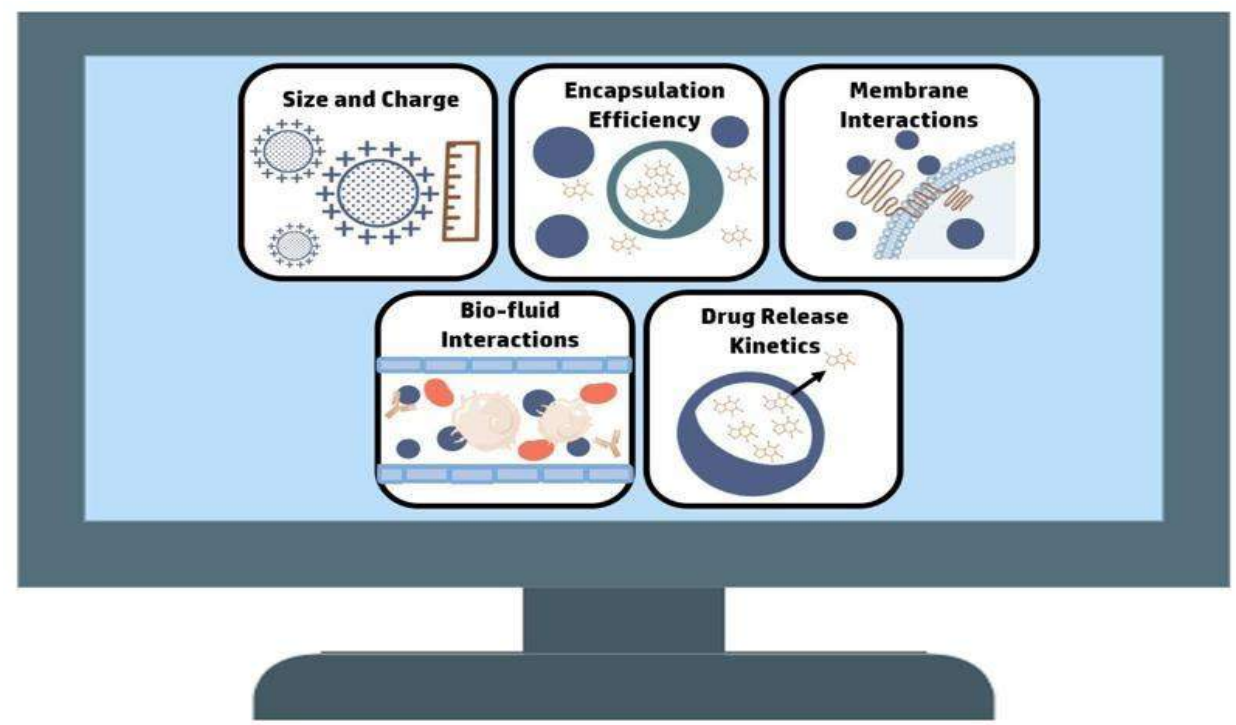

Figure 4. Computational methods contribute to various aspects of nanoparticle design

\section{Conclusion}

Al and nanotechnology are two critical technologies[26]. The ultimate goal is to integrate the uses and possibilities of these two technologies and work wonders in the healthcare domain[27].

The world is focused on medical possibilities and has understood the importance of health after COVID-19. It is time to write time to put effort at this crossroads. This research will benefit those working in Al and medicine[28][29].

Future research is expected to find personalized medicine is the current need because we can see many cases where acute situations can be handled only if these goals are adequately handled[30]. Integrating the power of $\mathrm{Al}$ and nanotechnology gives rise to various solutions in the medical domain[31].

\section{References}

[1] H. P. Yu and E. Jen, "Integrating Nanotechnology in the Science Curriculum for Elementary High-Ability Students in Taiwan: Evidenced-Based Lessons," Roeper Rev., vol. 42, no. 1, pp. 38-48, Jan. 2020, doi: 10.1080/02783193.2019.1690078.

[2] U. Rahardja, N. Lutfiani, A. Yolandari, J. Sistem Informasi, and S. Raharja, "Penerapan Viewboard Informatif Pada Asosiasi Perguruan Tinggi Swasta Indonesia Dalam Era Industri 4.0," Technomedia J., vol. 3, no. 2 Februari, pp. 224-234, Feb. 2019, doi: 10.33050/TMJ.V3I2.738.

[3] H. Hassani, E. S. Silva, S. Unger, M. Tajmazinani, and S. Mac Feely, "Artificial intelligence (AI) or intelligence augmentation (IA): what is the future?," mdpi.com, p. 1211, doi: 10.3390/ai1020008.

[4] S. Bayda, M. Adeel, T. Tuccinardi, M. Cordani, F. Rizzolio, and A. Baeza, "The history of nanoscience and nanotechnology: from chemical-physical applications to nanomedicine," mdpi.com, vol. 25, p. 112, 2020, doi: 10.3390/molecules25010112.

[5] U. Rahardja, N. Lutfiani, ... A. R.-2020 8th I., and undefined 2020, "Determinants of Lecturer Performance to Enhance Accreditation in Higher Education," ieeexplore.ieee.org, Accessed: Jan. $\quad$ 05, 2022. [Online]. Available: https://ieeexplore.ieee.org/abstract/document/9268871/. 
[6] S. Sudaryono, Q. Aini, N. Lutfiani, F. Hanafi, and U. Rahardja, "Application of Blockchain Technology for iLearning Student Assessment," IJCCS (Indonesian J. Comput. Cybern. Syst., vol. 14, no. 2, pp. 209-218, Apr. 2020, doi: 10.22146/IJCCS.53109.

[7] T. Ayuninggati, E. P. Harahap, Mulyati, and R. Junior, "Supply Chain Management, Certificate Management at the Transportation Layer Security in Charge of Security," Blockchain Front. Technol., vol. 1, no. 01, pp. 1-12, Jun. 2021, Accessed: Dec. 27, 2021. [Online]. Available: https://journal.pandawan.id/b-front/article/view/3.

[8] E. Lombi, E. Donner, M. Dusinska, F. W.-N. nanotechnology, and undefined 2019, "A One Health approach to managing the applications and implications of nanotechnologies in agriculture," nature.com, 2019, doi: 10.1038/s41565-019-0460-8.

[9] U. Rahardja, I. Handayani, N. Lutfiani, and F. P. Oganda, "An Interactive Content Media on Information System iLearning+," IJCCS (Indonesian J. Comput. Cybern. Syst., vol. 14, no. 1, pp. 57-68, Jan. 2020, doi: 10.22146/IJCCS.51157.

[10] U. Rahardja, N. Lutfiani, and H. L. Juniar, "Scientific Publication Management Transformation In Disruption Era," APTISI Trans. Manag., vol. 3, no. 2, pp. 109-118, Jul. 2019, doi: 10.33050/ATM.V3I2.1008.

[11] M. Nurchaerani, Haryati, and F. Nursyamsi, "Upaya Meningkatkan Minat Belajar Di Masa Pandemi Melalui Pelatihan Bahasa Inggris Secara Daring," ADI Pengabdi. Kpd. Masy., vol. 2, no. 1, pp. 1-7, Oct. 2021, doi: 10.34306/ADIMAS.V2I1.451.

[12] S. Purnama, A. Sukmasari, and R. Bhandari, "The Role of Religiosity as a Mediating Variable in the Relationship between Online Transactions and Customer Satisfaction and Loyalty in Islamic Banking," APTISI Trans. Manag., vol. 5, no. 2, pp. 143-151, Mar. 2021, doi: 10.33050/ATM.V5I2.1532.

[13] S. Mojtaba Mousavi, S. Alireza Hashemi, M. Zarei, and A. Mohammad Amani, "Nanosensors for chemical and biological and medical applications," researchgate.net, 2018, doi: 10.4172/2161-0444.1000515.

[14] S. Sudaryono, U. Rahardja, and D. Apriani, "The CICES Journal Governance Performance Improvement on Quality Of Current Issues (Case Study of STMIK RAHARJA)," APTISI Trans. Manag., vol. 3, no. 1, pp. 57-64, Feb. 2019, doi: 10.33050/ATM.V311.578.

[15] U. Rahardja, N. Lutfiani, and S. Amelia, "Creative Content Marketing In Scientific Publication Management In Industrial Era 4.0," APTISI Trans. Manag., vol. 3, no. 2, pp. 168-177, Aug. 2019, doi: 10.33050/ATM.V3I2.991.

[16] U. Rahardja, Q. Aini, F. Budiarty, M. Yusup, and A. Alwiyah, "Socio-economic impact of Blockchain utilization on Digital certificates," Aptisi Trans. Manag., vol. 5, no. 2, pp. 106111, Mar. 2021, doi: 10.33050/ATM.V5I2.1508.

[17] I. A. Kurniawan, D. Yusman, and I. O. Aprilia, "Utilization of Blockchain Technology Revolution in Electronic ID Card Data Integrity," APTISI Trans. Manag., vol. 5, no. 2, pp. 137-142, Apr. 2021, doi: 10.33050/ATM.V5I2.1530.

[18] W. Ramadayanti and K. Kosasih, "The Influence of Financial Performance on People's Business Credit in Banking Companies for the Period 2010-2019," APTISI Trans. Manag., vol. 5, no. 1, pp. 73-78, Jan. 2021, doi: 10.33050/ATM.V5I1.1435.

[19] T. Ramadhan, Q. Aini, S. Santoso, A. Badrianto, and R. Supriati, "Analysis of the potential context of Blockchain on the usability of Gamification with Game-Based Learning," Int. J. Cyber IT Serv. Manag., vol. 1, no. 1 SE-Articles, pp. 84-100, Apr. 2021, [Online]. Available: https://iiast-journal.org/ijcitsm/index.php/IJCITSM/article/view/24.

[20] P. Edastama, "The Importance of Maslahah Orientation in Sharia Institutions," APTISI Trans. Manag., vol. 5, no. 2, pp. 180-190, May 2021, doi: 10.33050/ATM.V5I2.1595.

[21] F. Ilmu Pengetahuan Islam Berbasis Teknologi Dalam Perspektif Epistemologi Zaharuddin et al., "Filsafat IImu Pengetahuan Islam Berbasis Teknologi Dalam Perspektif Epistemologi," Alph. J. Wawasan Agama Risal. Islam. Teknol. dan Sos., vol. 1, no. 1, pp. 1-15, Oct. 2021, Accessed: Dec. 27, 2021. [Online]. Available: https://journal.pandawan.id/al-waarits/article/view/23.

[22] T. Nurhaeni, N. Lutfiani, A. Singh, W. Febriani, and M. Hardini, "The Value of Technological Developments Based on An Islamic Perspective," Int. J. Cyber IT Serv. Manag., vol. 1, no. 1 SE-Articles, pp. 1-13, Apr. 2021, [Online]. Available: https://iiastjournal.org/ijcitsm/index.php/lJCITSM/article/view/4.

[23] E. Erlina and D. Hermawan, "Marketing Mix on Customer Loyalty at Coffee Shop in Bandung," APTISI Trans. Manag., vol. 5, no. 1, pp. 89-96, Jan. 2021, doi: 
10.33050/ATM.V5I1.1488.

[24] P. Hendriyati, F. Agustin, U. Rahardja, and T. Ramadhan, "Management Information Systems on Integrated Student and Lecturer Data," APTISI Trans. Manag., vol. 6, no. 1, pp. 1-9, Jul. 2022, doi: 10.33050/ATM.V6l1.1527.

[25] S. Watini, T. Nurhaeni, and L. Meria, "Development Of Village Office Service Models To Community Based On Mobile Computing," Int. J. Cyber IT Serv. Manag., vol. 1, no. 2 SEArticles, pp. 189-196, Oct. 2021, [Online]. Available: https://iiastjournal.org/ijcitsm/index.php/IJCITSM/article/view/51.

[26] U. Rahardja, Q. Aini, F. Budiarty, M. Yusup, and A. Alwiyah, "Socio-economic impact of Blockchain utilization on Digital Certificates," APTISI Trans. Manag., vol. 5, no. 2, pp. 106111, Mar. 2021, doi: 10.33050/ATM.V5I2.1508.

[27] Jerry Heikal, Vitto Rialialie, D. Rivelino, and Ign Agus Supriyono, "Hybrid Model Of Structural Equation Modeling Pls And Rfm (Recency, Frequency And Monetary) Model To Improve Bank Average Balance," Aptisi Trans. Technopreneursh., vol. 4, no. 1, pp. 1-8, Dec. 2021, doi: 10.34306/ATT.V4I1.221.

[28] A. Bagus Setiawan, W. Rachmawati, A. Taufiq Arrahman, N. Natasyah, and F. N. S. Fadil, "Aplikasi Monitoring Stok Barang Berbasis Web Pada PT. Intermetal Indo Mekanika," ADI Bisnis Digit. Interdisiplin J., vol. 2, no. 2, pp. 1-6, Sep. 2021, doi: 10.34306/ABDI.V2I2.254.

[29] A. Pambudi, R. Widayanti, and P. Edastama, "Trust and Acceptance of E-Banking Technology Effect of Mediation on Customer Relationship Management Performance," ADI J. Recent Innov., vol. 3, no. 1, pp. 87-96, Sep. 2021, doi: 10.34306/AJRI.V3I1.538.

[30] R. Z. Syahrir and Eri Prasetyo Wibowo, "Classification of Leaves Based on the Shape of Leaves Using Convolutional Neural Network Methods," IAIC Trans. Sustain. Digit. Innov., vol. 3, no. 1, pp. 1-7, Oct. 2021, doi: 10.34306/ITSDI.V3I1.491.

[31] Setiawansyah, H. Sulistiani, A. Yuliani, and F. Hamidy, "Perancangan Sistem Informasi Akuntansi Upah Lembur Karyawan Menggunakan Extreme Programming," Technomedia J., vol. 6, no. 1, Jun. 2021, doi: 10.33050/TMJ.V6I1.1421. 